\title{
Media Coverage of Malaysian Airline Flight MH370: A Preliminary Study on the Framing of the Crisis in the Malaysian Mainstream and Alternative Newspapers
}

\author{
LIM SHIANG SHIANG \\ IHEDIWA SAMUEL CHIBUNDU \\ SHARON JACQUELINE A/P ALBERT WILSON \\ Universiti Tunku Abdul Rahman
}

\begin{abstract}
This study proposes to investigate and compare the coverage of the disappearance of Malaysia Airlines flight MH370 by Malaysian mainstream and alternative newspapers - The Star newspaper and Malaysiakini. The MH370 crisis in March 2014 is considered as the greatest aviation crisis in the history of Malaysia because of its magnitude and attracted massive local and international media coverage. It presented Malaysian authorities with a new form of challenge, resulting in various criticisms from aviation, media and crisis communication experts over how information regarding the crisis was handled by Malaysia Airlines (MAS) in particular, and the Malaysian government in general. On the other hand, the role of the media during a crisis is not only to provide information regarding the crisis, but also to act as the peoples' advocate by providing an avenue for public engagements and discussions. However, the ability of the media to play this role depends to a certain extent on ownership, and a large extent on the degree of freedom it enjoys in a country. Through quantitative content analysis, the study compares the framing of the crisis by the selected newspapers, the sources of information for their news stories, and slants of the news. The study found that the mainstream newspaper The Star provided general and limited viewpoints with a concentration on the human interest frame, while the alternative newspaper, Malaysiakini, had more critical news reports with a focus on the attribute of responsibility frame.
\end{abstract}

Keywords: Crisis, framing, MH370, newspaper coverage, press freedom.

\section{INTRODUCTION}

When a Beijing-bound Malaysia Airlines flight MH370 mysteriously disappeared from radar one hour after take-off from Kuala Lumpur International Airport on March 8, 2014, people across the world thought that subsequent news stories on the incident would produce answers to the whereabouts of the airline. But as an hour to hour coverage turned into days and weeks, so did endless waiting turn into frustration and anger among victims' families, while local and international pressures mounted on Malaysian authorities to release definite information regarding the crisis.

Malaysia is not new to air crash incidents, as the country had in the past experienced several similar situations. On June 6, 1976, Flight Double Six crashed in a flight from Labuan to Kota Kinabalu airport, killing notable Malaysian politicians such as the Chief Minister of Sabah Tun Fuad Stephens, 3 state ministers, and the secretary of state for Finance, the Director of Economic planning unit, among others (Malaysian Digest, 2014). 
Again, on December 4, 1977, a domestic flight from Penang to Kuala Lumpur on a Boeing 737-200 crashed at Tanjung Kupang, Johor, killing 93 passengers and 7 crew members. Experts claim that the flight was hijacked once it had reached cruising altitude where the crew reported they had an 'unidentified hijacker'. Other examples include Malaysia Airlines Flight 2133 (MH2133) crash on September 15, 1995, which killed 32 persons, and the Japanese Airlines Flight 715 crash at Subang airport on September 27, 1977, among others (Malaysian Digest, 2014).

However, the number of foreign nationals on board the $\mathrm{MH} 370$, and how the airplane disappeared without a trace made the MH370 crisis as Philips (2016) stated, one of the most perplexing mysteries in aviation history. Rawle (2015) on the other hand noted that the MH370 disappearance provides no evidence as none of the black boxes or voice recorders have been found to date. This is against the backdrop that Malaysian government officials announced in January 2015 that the flight ended in the Southern Indian Ocean and that all passengers and crew on board were presumed dead, sparking off outrage from victims' families who were stunned at such declaration. Though debris was found in Reunion Island, Mauritius, and Tanzania in the year 2015 and 2016, there was no formal announcement to what exactly happened to the flight. The winning of the Pakatan Harapan government during the 14th Malaysian General Election perhaps gives hope as the new government is considering relaunching the search for the missing airline (The Star, 2019).

The study is significant because $\mathrm{MH} 370$ is considered not only as of the greatest aviation crisis in Malaysian history but also as one that has the potential to affect the bilateral relations between Malaysia and other countries in which nationals were on board the airline, particularly China. The majority of the passengers onboard the airlines were Chinese nationals. The crisis presented Malaysia with new experiences and challenges on how a crisis of global impact can make or mar the image of a country. Most studies on MH370 focus on the plan and strategies of crisis communication and crisis management (Junaidi, Mohd. Sahandri, \& Mazura, 2014; Peiter 2014; Kalthom et al., 2014; Lee \& Han, 2014). There are also few studies on the framing of the MH370 crisis by international media (Park, Bier \& Palenchar, 2016; Bier, Park \& Palenchar, 2017). They compared Malaysian media and Chinese media coverage of the crisis. However, the study of Malaysian media coverage of MH370 crisis is less explored. Therefore, this study will help fill the gap in the literature on aviation crisis reporting in Malaysian newspapers and deepen understanding of the media environment that results in the way Malaysian newspapers frame the $\mathrm{MH} 370$ crisis.

\section{LITERATURE REVIEW}

\section{Media and Crisis Communication}

Crises threaten us on all sides. It may happen in a "specific, unexpected, and non-routine event or series of events that create high levels of uncertainty and threaten or are perceived to threaten high priority goals" (Seeger, Sellnow \& Ulmer, 2003, p.204 -205). In defining a crisis, keywords such as "unrest", "conflict", "revolution" and "uncertainties" (Koselleck, 2006), "catastrophic' (Filippini, 2017) and "threat" (Jacques, 2014) are commonly used. Due to a high degree of uncertainty and anxiety, members of the society may go through disruption or emotional breakdown if it is not handled properly. 
Kotsiopoulos (2014) pointed out that people have a strong desire and are very much dependent on media for crisis information to ease tension and alleviate anxiety. On the other hand, the sensationalism in news is not uncommon as a media organisation originally aims for profit. Therefore, it is vital to understand how media and journalists function, particularly in disseminating crisis information. This is equally stressed by Sipon (2018) that media plays an important role as an official warning of the impending threat of a crisis and making people aware of the situation during a crisis. Media serves as a key channel for disseminating information before, during and after a crisis (Fu, Zhou, Zhang, Chan \& Burkhart, 2012). According to Parmer, et al. (2016), the public demands for "timely, empathetic and transparent" crisis information. This is so that people can make prompt responses, stay calm and maintain a higher level of personal safety and well-being. The failure to control crisis information will result in a failure to control the crisis, which further leads to major uncertainties. Hence, people expect the media to be the dominant sources as media are generally thought to be a valuable and timely source of information during a crisis.

In studying crisis communication and news media, Ohman, Nygren, and Olofsson (2016) concluded that crisis communication is not simply about mass media and risk communication, rather, it is significant to examine the unequal relations of power in a wider context where crisis communication has served as part to maintain the hegemonic power so that powerful ruling is able to manage and govern the uncertainties during the crisis. Working under a condition where there is no equal power-sharing, it may be difficult for journalists to be able to perform their roles. On the other hand, many communication scholars have emphasised the importance of journalists having access to information (Parmer et al., 2016) in order to report clear and concise risk information (Solomon, 2009). To provide further justifications, it is inevitable to tie it to the level of press freedom in the country. As emphasised by Wu, Cheng and Chao (2017), journalists with a higher level of freedom show more "initiative, directness, assertiveness, and adversarialness" as compared to those journalists with a lower level of press freedom.

Indeed, state controls and restrictions can silence critical media voices. In a study of media and crisis reporting, Ball (2018) found out that $59 \%$ of the people lost trust in media due to reasons such as "too biased" and "controlled by hidden agendas". This is also pointed out by another study by Bolin (2006) that Sri Lanka journalists have neglected the voice of people, rather journalists were used as a political propaganda tool to serve a certain political purpose. Ramasubramaniam and Miles (2018) stress the importance of free press because government controls and restrictions, as well as other political factors, often serve as a stumbling block for journalists to practice their roles during a crisis. Therefore, it implies that crisis communication is related to state context and many other factors. While people expect media to be a dominant source in communicating risk information, it is not possible if media are not given the freedom to perform its journalistic functions.

\section{Crisis Reporting and Press Freedom in Malaysia}

Crisis reporting in Malaysia is often downplayed due to the restrictions and controls in the country. Norsiah, Mohd Sobhi and Nazialita (2015) opine that Malaysian news and journalism practice is often bound by "ethics, rules and regulations" (p. 638), which claim to protect national security. Turow (2014) also referred to this scenario as one that allows the government to limit 
the way of news reporting and writing. This is supported by many other scholars (Teoh, Yang \& Neo, 2016; Yang \& Leong, 2017) that Malaysian news reporting is imbued with a certain ideological parameter, which leads to a certain degree of biases and favoritism.

In a study of media and news reporting in Malaysia, Ismail, Ahmad Mohd and Mustaffa (2017) have mentioned several internal and external challenges of the Malaysian journalism profession and newsroom practice. The external challenges include a lawsuit, information availability, issue availability, seeking the truth, weak enforcement and low impact. Additionally, Malaysian journalists also face another eight newsroom challenges internally, which include journalism skills, culture differences, time, risk, cost, human resources, attitude and media sustainability. The scholars added that four out of the internal challenges have a close link to government controls and restrictions. This implies that Malaysian journalists may have an interest in investigative journalism, however, state control and ownership restriction have undermined this interest and put the journalistic expression into silence.

In Malaysia, information is often curbed through coercion (military force, laws restrictions, etc.) and consent (through the negotiation of media text and reporting). There is a slew of laws and regulations that hamper media freedom and expression. This includes Printing Presses and Publication Act (PPPA), Official Secrets Act (OSA), Sedition Act, Security Offences (Special Measures) Act 2012 (SOSMA) and Communication and Multimedia Act (CMA). A typical case was during the 'operasi lalang' when three mainstream newspapers The Star, Watan and Sin Chew Daily were suspended for five months for supporting the Chinese school issue. This is not including many other journalists who were detained under the Internal Security Act during the earlier decades of the nineteenth century.

Though the rise of the Internet has given society new ways of engagement and exchange of information and opportunities, nevertheless, alternative news media such as Malaysiakini, Malaysian Insight, Free Malaysia Today have had a difficult journey in their quest to establish themselves. One of the typical cases that happened was when Malaysian Communication and Multimedia Commissions (MCMC) blocked the website of Free Malaysia Today under Sections 263 and 233 of Communication and Multimedia Act (CMA) (Mohd. Azizuddin, Muhammad Zaki \& Ratnaria, 2016). According to Malaysia Today (2008), the blocking was because some of the comments on the website were insensitive, bordering on incitement and could pose challenges to the authoritarian state.

Moreover, in September 2009 and 2010, several independent online news media and some opposition-related websites were attacked by a distributed denial-of-service (DDOS) for releasing a story on government corruption (Freedom House, 2015). Before the opposition party won the election in 2018, Malaysian Insider and Sarawak Report were also blocked due to their news reports on corruption in the country. Hence, legal authority gives the state an unlimited and uncontrolled power to create a situation where an authoritarian state could use the law as a cloak for the arbitrary use of power. This raises the question of the role of the media during a crisis as the definition of a free press was seen as a means to protect some political viewpoints. Therefore, it is vital to examine the framing of Malaysia media during the MH370 crisis, particularly the extent the media fulfilled its roles as an information provider and source of information. 


\section{An Overview of Framing}

Framing analysis provides the theoretical point for this study. Different from agenda setting theory, frame or framing research "expands beyond agenda setting research into what people talk or think about by examining how they think and talk about issues in the news" (Pan \& Kosicki, 1993, p.70).

Framing is an effective way to comprehend and understand the media roles during any event or crisis. Mishra (2011, p.24) stated that the "mass media set the frames of references that readers or viewers use to interpret and discuss public events". It organises ideas or storylines that provide meanings in telling the audiences what the problem of the crisis is or the essence of the issue. In the words of Neuman, Just and Crigler (1992, p. 60), news frames are "conceptual tools which media and individuals rely on to convey, interpret and evaluate information. "This is also enhanced by Entman (2004) that framing involves problem definition, causal interpretation, moral evaluation and treatment recommendation which play a vital role in organising ideas as well as shaping the news story while providing meanings to the news (Kim, 2006, p.7). Hence, the media frame can be very powerful and plays a critical role in shaping public understanding of the $\mathrm{MH} 370$ crisis. Audiences' attitudinal and behavioural reactions are influenced by the way news is being portrayed and framed, especially for members of victims' families. In short, the news or issue framed by the journalist is an active interpretation and media adoption where the audiences adopt and see the world in the same way the journalist does (Temmerman, 2012, p.124).

In the process of selection and salience, Chyi and McCombs (2004) elaborate that a single news event can be framed in various ways, providing different perspectives with different attributes of a story. Different frames could have different meanings and impacts. Semetko and Valkenburg (2000) have identified five common types of media frames, namely, conflict frame, human interest frame, morality frame, economic frame and responsibility frame, to be suitable in analysing issues related to conflict, economics, human impact, and morality.

In news framing, continuous communication between the journalists and the source is one of the important external factors that could affect the news frames. De Vreese (2005) stated that the importance of news sources in the framing process is building the "structural qualities of news frames". This is crucial to add authority and believability to their news by quoting reliable news sources to provide facts. Entman (1993) argued that to some extent, the source is the story. It is because the sources of news stories can determine the content of the news articles and thereby influence the angle the news is presented.

In a frame-building process, it is vital to consider the interaction between media and news sources. According to a study by Chang, Faridah, Fauziah, and Chew (2012), news sources or frame sponsors are more influential in the frame-building process. Frame sponsors play a vital role in influencing the frame-building mainly because they are the ones who make efforts to frame information in news stories. This could be critical as news information is framed in a way that prioritises the frame sponsor instead of the people. This has also been supported by Stromback, Shehata, and Dimitrova (2008) that journalists and editors tend to passively turn to official and established news sources, and this is perhaps due to the restrictions in the country. In view of this, journalists are merely echoing frame sponsors or act as transmitters of official viewpoints. 
Slant is another news frame used by many researchers. Entman (2010, p. 392) stated that "Slant occurs when a news report emphasizes one side's preferred in a political conflict while ignoring or derogating another side. One-sided framing emphasizes some elements and suppresses others in ways that encourage recipients to give attention and weight to the evaluative attributes that privilege that favoured side's interpretation. This is the essence of slanted news." News slant can either be supportive or critical of a group or individual. In a study by Lai and Md Sidin (2012), Utusan Malaysia appeared to be more critical than Sin Chew Daily in framing the Hindraf demonstration. More often, Utusan Malaysia projected the demonstration in a very negative way due to the contradicting objectives of the demonstration which appears to have challenged the Malay privileges. Therefore, the newspaper, owned by a group of UMNO members felt threatened and consequently portrayed the demonstration negatively. This implies that the slant of a newspaper is mostly influenced by a range of causal factors including the political, economic and social context in the country.

\section{METHODOLOGY}

This study employed a quantitative content analysis method to collect empirical data for analysis of the communication phenomenon. This approach has over the years been used by communication researchers to study almost all forms of communications, particularly, because of its descriptive and inductive way of hypothesis testing.

A quantitative content analysis approach was used to extract information from Malaysia's highest-circulation newspaper, The Star (average net circulation 286,436 - July to December 2014 -Audit Bureau of Circulations Malaysia) and the alternative newspaper, Malaysiakini which ranks number one alternative news website in Malaysia, with more than 1.18 million unique visitors per month (Malaysiakini formal website). Malaysiakini is an independent online newspaper that publishes critical news on issues related to the country's politics and helps to ensure a transparent government through citizens' engagements and participation. Though $\mathrm{MH} 370$ is considered an aviation crisis, there is a political undertone to it, given the bilateral relations between Malaysia and other countries, especially China. Also, there are many criticisms of Malaysian government's lack of transparency in handling the crisis, including the shipping of mangosteen being off-season, the failure of Malaysian immigration to identify the two imposters as well as the inconsistent searching and information dissemination (Aidila Razak, 2014; Hookway, Jason Ng \& Chomchuen, 2014; Zafra \& Maydell, 2018). Therefore, Malaysiakini played an important role in monitoring the government and providing alternative viewpoints about the crisis. This is proven considering the frequency at which Malaysiakini reported the crisis which is comparable to the volume of articles published by The Star on the issue. Additionally, the shifting of the media landscape to online news media has been proven in most journalism and communication studies. Therefore, comparing these two Malaysian news media (mainstream print and alternative online) that have the highest circulation rate in the country could provide an insight into how different types of newspapers differ in their framing of the MH370 crisis.

The sample was drawn from the 8th of March 2014 to the 14th of March 2014, which represents the peak period of MH370 crisis. A total of 187 news articles were extracted from both newspapers with 84 news articles from Malaysiakini and 103 from The Star. The news articles were selected from the local section, international section, and 
opinion/columns/commentaries. The coding of the articles was done sentence by sentence to ensure that more detail information is obtained from the newspapers' articles. Types of frames, the slant of news and news sources were examined.

Concerning the operational definitions of the news frame, five generic frame dimensions developed by Semetko and Valkenburg (2000), namely, responsibility frame, conflict frame, morality frame, economic consequences frame, and human interest frame were adapted. The aim was to identify the dimensions of the frame that featured prominently in each of the newspapers during the period of coverage.

- Responsibility frame: The frame suggests that authorities, individuals or groups are taking responsibility and have the ability to solve the problem.

- Conflict frame: This frame focuses on the conflict angles of an issue such as arguments and disagreements between two parties.

- Morality frame: issues are examined through the lens of moral values and religious teaching where reference is made to morality, God and other religious tenets.

- Economic consequences frame: Events and problems are highlighted in terms of the economic consequences on individuals, groups and the country in general.

- Human interest frame: In this frame, attention is given to elements that could touch on the emotions of the readers.

To ensure the validity and reliability of this study, two communication graduates were trained as the second and third coders. A test coding with the selection of a $10-25 \%$ sample of the news articles (Riffie, Lacy \& Fico, 2005) is a crucial step before conducting a full-scale content analysis to avoid any inconsistencies and inadequacies (Devi 2008). Therefore, $10 \%$ which is 20 articles from both Malaysiakini and the Star were tested. Using Holsti's formula (Wimmer \& Dominick, 2006), it was found that the intercoder reliability was 0.95 which means the coding is valid and reliable.

\section{FINDINGS}

Malaysiakini and The Star framed the MH370 crisis in different ways. Findings show that Malaysiakini emphasised the attribution of responsibility frame and provided more critical slants. In contrast, The Star focuses more on the human interest frame and provided more supportive slants. Nevertheless, both newspapers focused on the government as a source of information during the crisis. The result can be found in the following tables.

Table 1: Types of News Frame

\begin{tabular}{lcccc}
\hline \multicolumn{1}{c}{ Types of News Frame } & \multicolumn{2}{c}{ The Star } & \multicolumn{2}{c}{ Malaysiakini } \\
& Frequency & Percentage & Frequency & Percentage \\
\hline Economic Consequence & 0 & $0 \%$ & 15 & $4.4 \%$ \\
Conflict & 6 & $2.6 \%$ & 47 & $13.9 \%$ \\
Attribution of Responsibility & 79 & $34.5 \%$ & 198 & $58.4 \%$ \\
Morality & 3 & $1.3 \%$ & 25 & $7.4 \%$ \\
Human Interest & 141 & $61.6 \%$ & 54 & $15.9 \%$ \\
Total & $\mathbf{2 2 9}$ & $\mathbf{1 0 0 \%}$ & $\mathbf{3 3 9}$ & $\mathbf{1 0 0 \%}$ \\
\hline
\end{tabular}


A total of 568 sentences mentioned different types of frames in both Malaysiakini and The Star. As shown in Table 1 above, The Star employed human interest frame (61.6\%), followed by the attribution of responsibility frame (34.5\%). The conflict frame was at $2.6 \%$, morality frame at $1.3 \%$ while the consequences frame was not featured. Generally, The Star paid more attention to the victims' families' emotions as well as the background of the pilot and crew members. In contrast, Malaysiakini used attribution of responsibility (58.4\%) as the most frequent frame followed by human interest frame (15.9\%), conflict frame (13.9\%), morality frame $(7.4 \%)$ and lastly economic consequence frame (4.4\%). Most of the Malaysiakini news reports were either urging or prompting the Malaysian government to take further action on the $\mathrm{MH} 370$ crisis as contradictory information and rumours were spreading widely.

Table 2: Chi-Square Tests of Frame

\begin{tabular}{lccc}
\hline & Value & df & Asymp. Sig. (2-sided) \\
\hline Pearson Chi-Square & $137.806^{\text {a }}$ & 4 & .000 \\
Likelihood Ratio & 148.185 & 4 & .000 \\
Linear-by-Linear Association & 118.811 & 1 & .000 \\
N of Valid Cases & 568 & &
\end{tabular}

a. 1 cells $(6.3 \%)$ have expected count less than 5 . The minimum expected count is 4.11 .

Table 2 above shows a chi-square test conducted to understand the relationship between the five different types of frames (economic consequence frame, conflict frame, attribution of responsibility frame, morality frame and human interest frame). The results indicate that 0 cells (.0\%) have an expected count of less than 5 . This means that the result has not violated the assumption as all our expected cell sizes are greater than 5 (in our case greater than 6.05). The value of 0.000 is smaller than the alpha value of 0.05 , therefore it can be concluded that the result is significant. In other words, it means that there is a significant difference between the types of frames used in The Star and the ones in Malaysiakini. 
Table 3: Types of News Source

\begin{tabular}{|c|c|c|c|c|}
\hline \multirow[t]{2}{*}{ News Source } & \multicolumn{2}{|c|}{ The Star } & \multicolumn{2}{|c|}{ Malaysiakini } \\
\hline & Frequency & Percentage & Frequency & Percentage \\
\hline Expert & 43 & $9.2 \%$ & 18 & $2.7 \%$ \\
\hline International Community & 63 & $13.5 \%$ & 60 & $9 \%$ \\
\hline Government & 220 & $47 \%$ & 387 & $57.8 \%$ \\
\hline Non-Governmental Organisation & 14 & $3 \%$ & 11 & $1.6 \%$ \\
\hline Media & 26 & $5.6 \%$ & 102 & $15.2 \%$ \\
\hline Opposition & 2 & $0.4 \%$ & 8 & $1.2 \%$ \\
\hline Victim family \& friend & 62 & $13.2 \%$ & 12 & $1.8 \%$ \\
\hline Public & 38 & $8.1 \%$ & 72 & $10.7 \%$ \\
\hline Total & 468 & $100 \%$ & 670 & $100 \%$ \\
\hline
\end{tabular}

The two newspapers (The Star and Malaysiakini) provided a total of 1138 sentences regarding news sources (as shown in Table 3 above). Prominent among the sources are the government sources which accounted for $47 \%$ of the total number of sources for The Star and $57.8 \%$ for Malaysiakini. More often, both newspapers relied heavily on the Minister of Information and the police chief among others, for information updates. However, the second source of information for The Star (13.2\%) was victims' family members and friends, while members of the media were the second sources of information (10.7\%) for Malaysiakini.

Table 4: Chi-Square Tests of Source

\begin{tabular}{llll}
\hline & Value & df & Asymp. Sig. (2-sided) \\
\hline Pearson Chi-Square & $117.488^{\mathrm{a}}$ & 7 & .000 \\
Likelihood Ratio & 121.251 & 7 & .000 \\
Linear-by-Linear Association & .194 & 1 & .659 \\
N of Valid Cases & 1138 & & \\
\hline
\end{tabular}

a. 1 cells (6.3\%) have expected count less than 5 . The minimum expected count is 4.11 .

Table 4 above is a chi-square test to understand the relationship between the different types of news sources (experts, the international community, government, non-governmental organisations, media, opposition parties, victims' families \& friends and public), which shows that 1 cell (6.3\%) has an expected count of less than 5 . This means that the result has violated the assumption as all our expected cell sizes were smaller than 5 (in our case greater than 4.11). The value of 0.000 is smaller than the alpha value of 0.05 , therefore it can be concluded that the finding is significant. In other words, it means that there is a significant difference between the news sources quoted in The Star and the ones quoted in Malaysiakini.

Table 5: Types of News Slant

\begin{tabular}{ccccc}
\hline News Slant & \multicolumn{2}{c}{ The Star } & \multicolumn{2}{c}{ Malaysiakini } \\
\hline & Frequency & Percentage & Frequency & Percentage \\
Critical & 7 & $29.2 \%$ & 145 & $82.9 \%$ \\
Supportive & 17 & $70.8 \%$ & 30 & $17.1 \%$ \\
Total & $\mathbf{2 4}$ & $\mathbf{1 0 0 \%}$ & $\mathbf{1 7 5}$ & $\mathbf{1 0 0 \%}$ \\
\hline
\end{tabular}


On slants of news, a total of 199 sentences were written either in critical slant or supportive slant in the two newspapers. As could be seen in Table 5 above, $70.8 \%$ of news stories from The Star were very supportive of the Malaysian government's investigation of the missing airline. In contrast, Malaysiakini provided more critical views on the crisis, with $82.9 \%$ of its news stories being critical of the Malaysian government's handling of the crisis.

Table 6: Chi-Square Tests of Slant

\begin{tabular}{lccccc}
\hline & Value & df & $\begin{array}{c}\text { Asymp. Sig. } \\
\text { (2-sided) }\end{array}$ & $\begin{array}{c}\text { Exact Sig. } \\
\text { (2-sided) }\end{array}$ & $\begin{array}{c}\text { Exact Sig. } \\
\text { (1-sided) }\end{array}$ \\
\hline $\begin{array}{l}\text { Pearson Chi-Square } \\
\text { Continuity Correction }\end{array}$ & $33.725^{\mathrm{a}}$ & 1 & .000 & & \\
$\begin{array}{l}\text { Likelihood Ratio } \\
\text { Fisher's Exact Test }\end{array}$ & 30.815 & 1 & .000 & & \\
$\begin{array}{l}\text { Linear-by-Linear Association } \\
\text { N of Valid Cases }\end{array}$ & 38.237 & 1 & .000 & .000 & \\
\hline a. $\quad$ 0 cells (.0\%) have expected count less than 5. The minimum expected count is 5.67.
\end{tabular}

Table 6 above are the results of a chi-square test to understand the relationship between the different slants of news frame (critical or supportive) of the $\mathrm{MH} 370$ incident, showing that 0 cells $(.0 \%)$ have an expected count less than 5 . This means that the result has not violated the assumption as all our expected cell sizes were smaller than 5 (in our case greater than 5.67 ). The value of 0.000 is smaller than the alpha value of 0.05 , therefore it can be concluded that the finding is significant, as the slant of news coverage in The Star and Malaysiakini are significantly different from each other.

\section{DISCUSSION}

Generally, the disappearance of the MH370 received massive media coverage from both local and international media. This is evidenced in the number of news stories reported (187) by The Star and Malaysiakini within 7 days of the incident. It should be noted that even though the two Malaysian newspapers had provided adequate coverage of the crisis, yet the frame in which they reported the crisis differ. The analysis of the frames, sources and slants used show that there are significant differences between The Star and Malaysiakini in their coverage of the crisis.

The mainstream newspaper The Star featured the human interest frame prominently compared to other types of frames. It focused on the emotions of the victims' families', highlighting the background of the crew members. For example, on 14 March 2014, the paper reported that "the 35-year-old stunt master (victim), who worked as kung fu star Jet Li's stunt double, had planned a quick trip to Beijing to visit his two sons, aged five and one, as well as to collect work materials for his latest project". This news story is trying to focus the attention of the readers to the victims' families rather than providing factual analysis of what happened to the flight. While it is equally fair to state that The Star used the attribute of responsibility frame in some of its news stories, it is important to note that most of the news stories are skewed towards establishing the fact that the government and the Malaysian Airline Authority (MAS) were trying hard to resolve the mystery surrounding the disappearance of the airplane. This to us could be called "framing 'the attribute of responsibility frame'". By this, we mean a situation 
where the media deliberately selected the kind of responsibility frame it wants the readers to focus on (selective responsibility frame). This is supported by the MH370 study by Park, Bier, and Palenchar (2016) that Malaysian newspaper, New Straits Times, employed the ethical behavior frame, cooperation frame, and the leadership frame to support the Malaysian global image and reputation. The news media can have a critical role in shaping public opinion about who is responsible for causing the problem or crisis. In this study, the news media must be able to provide a balance responsibility frame to the audience to ensure that all sides of a story are covered. However, most of the responsibility frames were selectively chosen to support government actions in handling the crisis.

In contrast, Malaysiakini emphasised the attribute of responsibility frame. Most of Malaysiakini's reports were very clear that the government should bear responsibility for the

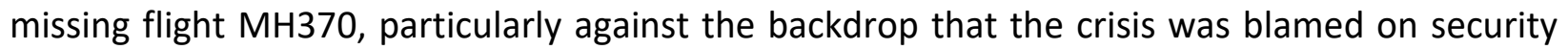
lapses. For example, on March 10, 2014, it reported Interpol secretary general Ronald K. Noble stating that "If MAS and all airlines worldwide were able to check the passport details of prospective passengers against Interpol's database, and then we would not have to speculate whether stolen passports were used by terrorists to board MH370". On the other hand, it is surprising to find out that within the seven days following the crisis, The Star paid zero percent attention to the economic consequences frame; while Malaysiakini devoted $4.4 \%$ to the economic consequences of the crisis.

This finding is in line with An and Gower (2009) who said that during a crisis, the more serious newspapers will focus on the attribute of responsibility frame; conflict frame as well as the economic consequences frames. Also, the finding corroborates Chang, Nor Syazwani, Norliana and Kho (2013) who found that the mainstream newspaper, Utusan Malaysia and the online alternative newspaper, Malaysiakini differ in their use of framing in the coverage of Bersih 3.0. Malaysiakini in the present study was able to take into consideration all the five different kinds of news frames as developed by Semetko and Valkenburg (2000) than The Star.

Regarding the news sources, both The Star and Malaysiakini newspapers were on the same pedestal in quoting government sources in their coverage of the crisis. It is not surprising that media practitioners tend to refer to official sources because they consider them as the most authoritative and reliable sources. Quoting official sources during a crisis can be important, yet it could pose a double crisis when conflicting information are coming from the very sources that journalists are supposed to trust. This is why the American Broadcasting Company (ABC) (2015, March 8) reported that most of the Malaysian news reports were lacking details and unsure of "what authorities were doing". It further stated that a lot of conflicting and unverified information was discovered, including the alleged report that four imposters were onboard the plane. In view of this, Flight magazine's global operations and safety editor David Learmount stated that the problem is that the various government agencies are not communicating effectively (Malaysiakini, 2014, March 12) and this was supported by the international media that the chaotic and contradictory responses from the Malaysian government made it worse (Mintz, 2014). The international media was urging the Malaysian media and Malaysian authorities to perform their roles as people were struggling for information. This scenario is depicted when on March 10, 2014, the Guardian online newspaper reported that a Chinese Foreign Ministry spokesman mentioned that China had been urging the Malaysian government to speed up search 
and rescue efforts and to also find out what had happened, adding that he hopes that "Malaysia will fully understand the emergent mood of Chinese family members".

On the other hand, the second-highest news source in The Star were the victims' families and friends. By using this source, the newspaper was aiming at emphasising the emotions of members of the victims' families and the background of the victims. But the media was the second-highest news source for Malaysiakini, as this source provided diverse points of view particularly when it drew a comparison between international media and the local media's coverage of the crisis. In the reporting of airport security lapse, Malaysiakini (2014, March 10) reported that The Independent of the United Kingdom posed a question with news heading "stolen passports revelation in Malaysia Airline crash exposes an alarming flaw in-flight security". Likewise, The Sydney Morning Herald and The Telegraph also raised a question over a security loophole, entitled "Can't immigration officials think" and "Malaysia plane crash: debris spotted as investigators probe passport link".

During a crisis, it is a norm that the country where the crisis had occurred becomes the main source where the press and other members of the media obtain updates with regard to the matter. It is questionable when the local newspapers start to cite foreign sources other than the local source. To further discuss the matter, it is vital to tie it to the wider Malaysian context. In discussing the Malaysian context, scholars have related it to semi-democracies (Smith, 2005), quasi-democracy (Case, 2011) and competitive authoritarianism (Johansson, 2015). Pepinsky (2009, p.115) further pointed out that Malaysia "elections are integral to the regime's stability but where they are neither free enough nor fair enough to be democratic". More often, there is a lack of freedom of expression and access to information. Additionally, all mainstream media are directly or indirectly controlled and owned by the government. Under such restricted conditions, mainstream newspapers can never antagonise its owner, nor will they challenge the national interest. In contrast, alternative media is not required to apply for a permit to run a newspaper, and therefore it is more open in expressing ideas and producing more critical news content. It should be noted however that in a semi-democratic country like Malaysia, it has not been easy for the alternative newspapers to have access to information. In other words, the newspapers could be critical as compared to mainstream newspapers, yet information access is still the biggest challenge encountered by journalists. Kenyon and Marjoribanks (2007) have mentioned that Malaysian journalists work in an environment that suit s certain kind of Malaysian culture of "responsible journalism" and undermine investigative reporting and the ability to provide critical comment in reporting of crises. Consequently, journalism is considered as a means to a financial end rather than serving the public (Tamam, Jalarajan \& Govindasamy, 2012). This is shown in this study where alternative newspapers that often appear to be more resistant than mainstream newspapers will draw from foreign news sources (Couldry \& Curran, 2003) to enrich the news content. This could be one of the reasons why the findings show that Malaysiakini cited other media as the second-highest news source in reporting the $\mathrm{MH} 370$ crisis.

Most of the news reports in The Star did not portray the MH370's actors in a critical way, but attempted to support the Malaysian authorities for their hard work in the investigation. Words and phrases such as "did their best" and "working hard" were used in the reporting of the crisis. On 9 March 2014, The Star reported that "The authorities, in particular, Malaysia Airlines, did their best, under the most difficult of circumstances, to give us the latest and most accurate 
reports on a regular and sustained basis." The uncritical report indicates the fettered democracy and press freedom in the country which is in line with what Netto (2002) said that the mainstream media coverage on government policies is usually uncritical as it has a significant link with the government.

Malaysiakini, on the other hand, reported the crisis in a more critical slant. Most of the critical news in Malaysiakini pointed to the uncoordinated handling of the crisis by the Malaysian authorities, using words and phrases such as unverified information, no information update, useless, and frustration among others. One such instance was on March 13, 2014, when the online news portal wrote, "It's nearing a week and many, many people are beginning to get very, very frustrated with the Malaysian government's lack of transparency and seemly loss of direction in handling the crisis." In contrast to mainstream newspapers mostly owned by the government, alternative newspapers often draw a critical point in discussing social problems or crises due to their level of freedom. As pointed by Sharafa and Nik Norma (2018), alternative online newspapers are far more critical of the status quo, and often quite aggressive in opposing it. The authors emphasise the importance of Malaysian journalists, particularly from the mainstream media to be able to play its watchdog role. Hence, it is crucial that news can be written in a critical way as it raises questions and problems, drawing conclusions and solutions and enabling the journalist to think open-mindedly within alternative systems of thought. As mentioned by Paul and Elder (2006), journalists should be able to think critically by recognising national and cultural bias as well as learn to interpret events from multiple viewpoints.

This study contributes to scholarly literature on how Malaysian media frame news stories, particularly when the country is challenged by crises of international magnitude. Malaysian media coverage of $\mathrm{MH} 370$ crisis is less explored in extant literature. Most studies on MH370 focus on crisis communication and crisis management (Junaidi, Mohd. Sahandri, \& Mazura, 2014; Peiter, 2014; Kalthom et al., 2014; Lee \& Han, 2014). There are also some studies on framing that focus on media coverage of international crisis (Park, Bier \& Palenchar, 2016; Bier, Park \& Palenchar, 2017). The present study has helped to deepen understanding of Malaysia's political context which influences the manner in which crises news are framed.

\section{CONCLUSION}

It can be concluded that the difference in the framing, sources of information and slants of the news between the two newspapers background their ownership and control. While The Star newspaper is mainstream news, considered by most Malaysians as pro-government, Malaysiakini is an alternative online news portal, considered by many as a critical voice to the various public discourses on the political, economic, social, racial and religious issues in Malaysia.

Even though Malaysian alternative newspapers have more freedom than mainstream newspapers in crisis reporting, they are not free from restriction. In a crisis of hegemony, communication scholars have pointed out that democratic procedures in Malaysia are only allowed when it does not present itself as a threat to the hegemonic power of the ruling elites. To maintain hegemonic power, various means are used either by coercion or drawing consensus. Threatening to block websites and putting journalists in jail are coercive ways used to curb information. In an interview with CNN reporter Brian Stelter, The Malaysian Insider chief editor Jahabar Sadiq pointed out that in reporting MH370 crisis; certain newspapers deemed to be 
critical such as The Malaysian Insider were often barred from briefings and denied entry into press conferences. The Malaysian journalist has very little means of access to information and the most challenging is that Malaysian authorities are not used to being questioned; rather, they expect the journalist to accept the answers provided by them without question (Cable News Network, 2014). Considering that MH370 is an international crisis that can tarnish the image of the country, newspapers that are directly or indirectly controlled by the government through ownership and restrictions would face difficulties in having access to alternative information.

This study is not without limitations. The content analysis of Malaysian newspapers focuses on framing in news production. It does not provide details on how clear the information was to elicit a response from the people during the peak of the MH370 crisis. This study is just the first step into such research, and more research is necessary particularly regarding access to information from the perspective of victims' families and journalists.

The implication of this study is a critical need for freedom of the press and freedom of expression in Malaysia. Access to accurate information is vital for journalists to perform their duties during a crisis. Members of the public largely depend on the media for information updates during a crisis. This would not be possible without freedom for journalists to do their jobs. The study found that throughout the first week of $\mathrm{MH} 370$ crisis coverage, the main source of information for the journalists were government authorities. Most of the news stories focused on what the government said, and these stories lacked critical viewpoints. This is attributed to a lack of freedom of the press in the country, and this situation tends to reduce journalism practice in the country to mere "government said so journalism". With the enthronement of the new democratic government in Malaysia since May 2018, the issue of press freedom has continued to be at the forefront. Therefore, the findings of this study are expected not only to help focus the attention of the government on the issue of press freedom in the country but to also act wisely on it.

\section{BIODATA}

Lim Shiang Shiang is a postgraduate student at Universiti Tunku Abdul Rahman (UTAR), Kampar campus. She is also a lecturer at OUW Malaysia KDU Penang University College. Her primary research interests focus on media freedom and democratization, particularly in analysing the media content which is closely connected to politics, state and market; and ideological representation. Email: shiang2lim@gmail.com

Ihediwa Samuel Chibundu is an Assistant Professor in Faculty of Arts and Social Science, Universiti Tunku Abdul Rahman (UTAR), Kampar campus. His research area is Journalism, with particular interest in crisis reporting, investigative journalism and citizen journalism among others. Email: ihediwa@utar.edu.my

Sharon Jacqueline A/P Albert Wilson is an Assistant Professor in Faculty of Creative Industries, Universiti Tunku Abdul Rahman (UTAR), Sungai Long campus. Her research area is journalism, with particular interest in crime and media, police media relations, ethics and decision making and media research methodology. Email: sharon@utar.edu.my 


\section{REFERENCES}

Aidila Razak (2014). MH370 mangosteens not from Muar, clarifies IGP. Malaysiakini. Retrieved from https://www.malaysiakini.com/news/259711

American Broadcasting Company (ABC). (2015, March 8). Malaysia Airlines Flight MH370: Timeline of events. Retrieved from http://www.abc.net.au/news/2015-03-08/timeline-ayear-of-searching-for-mh370/6261778

An, S. K., \& Gower, K. K. (2009). How do the news media frame crises? A content analysis of crisis news coverage. Public Relations Review, 35, 107-112. doi: 10.1016/j.pubrev.2009.01.010

Ball, J. (2018). Distrust of social media is dragging traditional journalism down. The Guardian. Retrieved from https://www.theguardian.com/commentisfree/2018/jan/22/distrustsocial-media-traditional-journalism-fake-news

Bier, L. M., Park, S., \& Palenchar, M. J. (2017). Framing the flight MH370 mystery: A content analysis of Malaysian, Chinese, and U.S. media. International Communication Gazette, 80(2), 158 - 184. doi: 10.1177/1748048517707440

Bolin, A. (2006). In whose interest? A study of journalists' views of their responsibilities and possibilities within the mainstream press in Sri Lanka (Master thesis, University of Gothenburg). Retrieved from https://jmg.gu.se/digitalAssets/1284 /1284255_nr41.pdf

Cable News Network (CNN). (2014, March 23). Malaysian authorities vs. the media. Retrieved from https://www.youtube.com/watch?v=mOAVAMt71jQ

Case, W. (2011). Electoral authoritarianism and backlash: Hardening Malaysia, oscillating Thailand. International Political Science Review, 32(4), 438-457. doi: 10.1177/01925121 10385296

Chang, P. K., Faridah, I., Fauziah, A., \& Chew, C. K. (2012). Frame contention between news sources and news media: Framing the dispute of teaching mathematics and science in English. Asian Social Science, 8(5), 16-28. doi: 10.5539/ass.v8n5p16

Chang, P. K., Nor Syazwani, I., Norliana, H., \& Kho, S. N. (2013). Framing Bersih 3.0: Online versus traditional mass communication. Procedia Technology, 11, 161-168. doi: 10.1016/j.protcy.2013.12.176

Chyi, H. I., \& McCombs, M. E. (2004). Media salience and the process of framing: Coverage of the Columbine school shootings. Journalism and Mass Communication Quarterly, 81(1), 2235. doi: 10.1177/107769900408100103

Couldry, N., \& Curran, J. (2003). Contesting media power: Alternative media in a networked world. United States of America: Rowman \& Littlefield Publishers, Inc.

De Vreese, C. H. (2005). News framing: Theory and typology. Information Design Journal + Document Design, 13(1), 51-62. doi: 10.1075/idjdd.13.1.06vre

Devi, P. B. (2008). Content analysis: A method in social science research. In Lal Das, D. K., \& Bhaskaran, V. (Eds.), Research methods for social work. New Delhi: Rawat Publication.

Entman, R. M. (1993). Framing: Toward clarification of a paradigm. Journal of Communication, 43(4), 51- 58. doi: 10.1111/j.1460-2466.1993.tb01304.x

Entman, R. M. (2004). Projections of power: Framing news, public opinion, and U.S. foreign policy. Chicago: University of Chicago Press.

Entman, R. M. (2010). Media framing biases and political power: Explaining slant in news of Campaign 2008. Journalism, 11(4), 389-408. doi: 10.1177/1464884910367587 
Filippini, M. (2017). Using Gramsci: A new approach. London: Pluto Press.

Freedom House. (2015). Freedom on the net. Retrieved from https://freedomhouse.org/report/freedom-net/2012/Malaysia

Fu, K. W., Zhou, L., Zhang, Q., Chan, Y., \& Burkhart, F. (2012). Newspaper coverage of emergency response and government responsibility in domestic natural disasters: China-US and within-China comparisons. Health, Risk \& Society, 14(1), 71-85.

Hookway, J., Jason Ng, \& Chomchuen, W. (2014). Iranians using stolen passports on flight had no known terror ties. The Wall Street Journal. Retrieved from https://www.wsj.com/articles/passenger-with-fake-passport-was-iranian-1394524427

Ismail, A., Ahmad Mohd, K., \& Mustaffa, C. S. (2017). Investigative journalism in Malaysia: The battle between outside and inside newsroom challenges. SHS Web of Conferences, 33, e00079. doi: 10.1051/ SHS Web of Conferences 33, 00079.

Jacques, T. (2014). Issue and crisis management: Exploring issues, crises, risk and reputation. New York: Oxford University Press.

Johannsson, A. C. (2015). On the challenge to competitive authoritarianism and political patronage in Malaysia. Asian-pacific Economic Literature, 29(2). doi: 10.1111/apel.12114

Junaidi, A. B., Mohd. Sahandri, G. B. H., \& Mazura, M. M. (2014). Crisis management- Malaysian aviation tragedies. Multidisciplinary Studies, 1(77), 77-93. Retrieved from www.globalilluminators.org

Kalthom, H., Aida N. A., Mastura, I., Mohd Fauzi, K., Anidah, R., Mohaida, M., \& Syed Najmuddin, S.H. (2014). A preliminary study on effects of social media in crisis communication from public relations practitioners' views. Social and Behavioural Sciences, 155, 223-227. doi: 10.1016/j.sbspro.2014.10.283

Kenyon, A. T., \& Marjoribanks, T. (2007). Transforming media markets: The cases of Malaysia and Singapore. Australian Journal of Emerging Technologies and Society, 5(2), 103-118.

Kim, Y. S. (2006). Finding framing devices: Pattern of source selection in framed Korean online news media. Submitted for presentation consideration to the Journalism Studies division at the annual meeting of the International Communication Association in Dresden, Germany.

Koselleck, R. (2006). Crisis. Journal of the History of Ideas, 67(2), 357-400.

Kotsiopoulos, I. (2014). Social media in crisis management: Role, potential and risk. 2014 IEEE/ACM 7th International conference on Utility and Cloud Computing.

Lai, F. Y., \& Md. Sidin, A. I. (2012). Framing interethnic conflict in Malaysia: A comparative analysis of newspaper coverage on the Hindu Rights Action Force (Hindraf). International Journal of Communication, 6, 166-189. doi: 10.1177/1468796813482310

Lee, C., \& Han, L. (2014). Faith-based organizations and transnational voluntarism in China: A case study on Malaysia Airline MH370 incident. Voluntas: International Journal of Voluntary and Nonprofit Organizations, 20(4), 319-350. doi: 10.1007/s11266-014-9518-2

Malaysian Digest. (2014, December 29). Previous air disasters in Malaysian history. Retrieved from www.malaysiandigest.com/features/535143-previous-air-disasters-in-malaysianhistory.html 
Malaysia Today. (2008, August 29). The 'offending' article that got MT blocked. Retrieved from www.malaysia-today.net/archives/archives-2008/11952-theoffending-article-that-gotmt-blocked

Malaysiakini. (2014, March 10). Airport security lapse makes world news. Retrieved from https://www.malaysiakini.com.libezp.utar.edu.my/news/256605

Malaysiakini. (2014, March 12). Aviation experts rap Malaysian authorities. Retrieved from http://www.malaysiakini.com/news/256829

Mintz, Z. (2014). A disastrous void: Why the MH370 public response failed. International Business Times. Retrieved from http://www.ibtimes.com/disastrous-void-why-mh370-publicresponse-failed-1598774

Mishra, N. (2011). Power to define: Framing of Naxalites in the Indian media. GMJ: Mediterranean Edition, 6(2), 23-35.

Mohd Azizuddin, M. S., Muhammad Zaki, A., \& Ratnaria, W. (2016). Freedom of the Internet in Malaysia. The Social Science, 11(7), 1343 - 1349.

Netto, A. (2002). Media in divided societies: Malaysia. Media Asia, 29(3), 179-183. doi: 10.1080/01296612.2002.11726686

Neuman, W. R., Just, M. R., \& Cirgler, A. N. (1992). Common knowledge - News and the construction of political meaning. Chicago: University of Chicago Press.

Norsiah, A. H., Mohd. Sobhi, I., \& Nazialita, G. M. (2015). Empowering citizen media through investigative journalism in Malaysia. Jurnal Komunikasi: Malaysian Journal of Communication, 3(2), 631-647.

Ohman, S., Nygren, K. G., \& Olofsson, A. (2016). The (un)intended consequence of crisis communication in news media: A critical analysis. Critical Discourse Studies, 13(5), $515-$ 530. doi: 10.1080/17405904.2016.1174138

Pan, Z., \& Kosicki, G. M. (1993). Framing analysis: An approach to news discourse. Political Communication, 10, 59-79. doi: 10.1080/10584609.1993

Park, S., Bier, L. M., \& Palenchar, M. J. (2016). Framing a mystery: Information subsidies and media coverage of Malaysia airlines flight 370. The International Communication Gazette, 42(4), 654-664. doi: 10.1177/1748048517707440

Parmer, J., Baur, C., Eroglu, D., Lubell, K., Prue, C., Reynolds, B., \& Weaver, J. (2016). Crisis and emergency risk messaging in mass media news stories: Is the public getting the information they need to protect their health?. Health Communication, 31(10), 12151222. doi: $10.1080 / 10410236.2015 .1049728$

Paul, R., \& Elder, L. (2006). The thinkers guide: For conscientious citizens on how to detect media bias \& propaganda in national and world news. The Foundation for Critical Thinking. Retrieved from www/criticalthinking.org

Peiter, N. (2014). The two Malaysia airlines disasters in 2014: Lessons for airline management in a global context. Proceedings of World Business, Finance and Management Conference.

Pepinsky, T. B. (2009). The 2008 Malaysian elections: A end to ethnic politics? Journal of East Asian Studies, 9(1), 87-120. Retrieved from http://www.jsor.org/stable/23418684

Phillips, T. (2016, March 8). MH370: Two years on, mystery still no closer to a solution. Guardian. Retrieved from https://www.theguardian.com/world/2016/mar/08/mh370-two-yearson-malaysia-airlines-mystery-still-no-closer-to-a-solution 
Ramasubramanian, S., \& Miles, C. (2018). Framing the Syrian refugee crisis: A comparative analysis of Arabic and English news sources. International Journal of Communication, 12, 4488-4506.

Rawle, T. (2015, June 9). MH370: Missing Malaysia Airlines plane nosedived into Indian ocean. Daily Star. Retrieved from http://www.dailystar.co.uk/news/latestnews/447040/MH370-Missing-Malaysia-Airlines-plane-nosedived-Indian-Ocean

Riffe, D., Lacy, S., \& Fico, F. G. (2005). Analyzing media messages: Using quantitative content analysis in research. New Jersey: Lawrence Erlbaum Associates.

Seeger, M. W., \& T. Sellnow, \& R. R. Ulmer. (2003). Communication and organizational Crisis. Westport, CT: Praeger.

Semetko, H. A., \& Valkenburg P. M. (2000). Framing European politics: A content analysis of press and television news. Journal of Communication, Spring 50(2), 93-109. doi:10.1111/j.14602466.2000.tb02843.x

Sharafa, D., \& Nik Norma, N. H. (2018). Framing the sustainable development goals in Malaysian online news. SEARCH, 1(1), 1-24.

Sipon, S. (2018). Understanding Malaysian Malays communication characteristics in reducing psychological impact on flood victims. Jurnal Komunikasi: Malaysian Journal of Communication, 34(1), 20-36.

Smith, P. H. (2005). Democracy in Latin America: Political change in comparative perspective. Oxford: Oxford University Press.

Solomon, W. (2009). News hole. In C. H. Sterling (Ed.), Encyclopedia of journalism. Thousand Oaks, CA: Sage.

Stromback, J., Shehata, A., \& Dimitrova, D. V. (2008). Framing the Mohammad cartoons issue: A cross-cultural comparison of Swedish and US Press. Global and Communication, 4(2), 117138. doi: $10.1177 / 1742766508091516$

Tamam, E., Raj, S. J., \& Govindasamy, M. (2012). Malaysian journalists. In, The global journalist in the 21st century. New York: Routledge Taylor \& Francis Group.

Temmerman, M. (2012). Naming and framing in Belgian politics: An analysis of the representation of politicians and the political state of affairs during the 2007 government formation period in the Belgian press. Belgian Journal of Linguistics, 24, 120-138. doi: 10.1075/bjl.24.06tem

Teoh, Y. C., Yang, L. F., \& Neo, D. H. J. (2016). Framing diplomatic relations: A comparative analysis of Malaysian and Chinese Newspapers coverage of Najib's visit to China. SEARCH, 8(2), 34-47.

The Guardian. (2014, March 10). Malaysia Airlines flight MH370: Officials widen search area. Retrieved from https://www.theguardian.com/world/blog/2014/mar/10/malaysia-airlin es-flight-370-search-continues-live-updates

The Star. (2019, March 8). MH370 remains world's greatest aviation mystery. Retrieved from https://www.thestar.com.my/news/nation/2019/03/08/mh370-remains-worldsgreatest-aviation-mystery

Turow, J. (2014). Media today: An introduction to mass communication (5th Ed). New York: Routledge. 
Wimmer, R. D., \& Dominick, J. R. (2006). Mass media research: An introduction. Belmont: Wadsworth.

Wu, F., Cheng, Y., \& D. Chao. (2017). Global questioners: Examining journalists' aggressiveness at Chinese premiers' press conferences (1993- 2015). Asian Journal of Communication, 27(4), 357 -377. doi: 10.1080/01292986.2017.1281322

Yang, L. F., \& Leong, W. K. (2017). Framing the Cow-head protest: A comparative analysis of The Star and Malaysiakini. SEARCH, 9(1), 71-96.

Zafra, N., \& Maydell, E. (2018). Facing the information void: A case study of Malaysia airlines' media relations and crisis communication during the MH370 disaster. Asia Pacific Public Relations Journal, 19, 41-65. 